\title{
ILCEA
}

Revue de l'Institut des langues et cultures

d'Europe, Amérique, Afrique, Asie et Australie

9 | 2007

L'implicite et les écrits de l'entreprise

\section{Case Study: Danone}

The ideas behind the words

\section{Chris Durban}

\section{(2) OpenEdition \\ 1 Journals}

\section{Electronic version}

URL: http://journals.openedition.org/ilcea/702

DOI: 10.4000/ilcea.702

ISSN: 2101-0609

\section{Publisher}

UGA Éditions/Université Grenoble Alpes

\section{Printed version}

Date of publication: 15 December 2007

Number of pages: 147-152

ISBN: 978-2-84310-104-5

ISSN: 1639-6073

\section{Electronic reference}

Chris Durban, «Case Study: Danone », ILCEA [Online], 9 | 2007, Online since 09 June 2010, connection on 21 April 2019. URL : http://journals.openedition.org/ilcea/702 ; DOI : 10.4000/ilcea.702

(C) ILCEA 


\title{
Case Study : Danone
}

\section{The ideas behind the words}

\author{
Chris DuRBaN \\ Traductrice indépendante
}

ABSTRACT

Mission statements, corporate values and social responsibility are three particularly tricky areas for translators specializing in corporate documents, since source texts themselves are often abstract, even abstruse. This contribution explains how professional translators, working closely with clients, identified implicit content in texts produced by French food group Danone and used this to find effective English equivalents.

\section{RÉSUMÉ}

Les textes exposant la mission et les valeurs d'une entreprise, tout comme ceux décrivant sa politique de responsabilité sociale, constituent un défi considérable pour le traducteur spécialise en communication d'entreprise, pour la simple raison que les textes sources sont souvent eux-mêmes abstraits voir abscons. Partant de textes rédigés par le Groupe Danone en langue française, l'auteur explique comment une équipe de traducteurs s'est prise pour dépasser l'explicit, cerner le message sous-jacent, et créer des équivalents en langue anglaise.

\section{Key words}

Corporate translation, corporate culture, corporate communications, mission statements, corporate values, implicit.

\section{Mots clés}

Traduction de documents d'entreprise, culture d'entreprise, communication d'entreprise, charte de l'entreprise, valeurs de l'entreprise, l'implicite. 
Pointing out that a lot of corporate writing is patchy, opaque or downright poor is stating the obvious.

The culprit may be committee writing. It may be over-use of jargon by in-house staff immersed in buzzwords. Or it may simply be texts produced by writers whose expertise lies in fields light-years from communicative writing: these people are brilliant accountants or financial analysts or human resource managers or website designers, but word flow is not their thing.

In other cases, texts that appear well-written at first sight are too inward-looking to have much impact on the world at large, and must be reworked before translation begins ${ }^{1}$.

Yet there are also many corporate texts that are very carefully crafted indeed, both carefully planned and meticulously written.

This being the case, our question is rather why so many business documents are so sloppily translated, even those at the top end of the market - immediately identifiable as "just a translation".

Needless to say, cries of "garbage in, garbage out" have no place in the premium "for-publication" segment. Nor does a proclaimed commitment to "faithfulness" to the explicit content of a source text excuse perpetrators of awkward translations (especially since this is more often than not uttered weakly, after the fact, once criticism has been voiced).

No, clearly, if the objective is to inform, persuade or sell, the translation must do just that, whatever the source text. Work produced must be informed by the translator's in-depth knowledge of the client's aims and corporate culture, the context in which the text will be used, and so on. It is the translator's job to gather all the information needed to achieve this, and failure to do so is, simply unprofessional.

\section{Start with a store of knowledge}

A client-education brochure published by ATA and ITI advises customers to develop an on-going relationship with a translator or team of

1. An example cited by European Central Bank press officer, Jean Rodriguez, was a 10-language brochure commissioned as an introduction to the European Union's new currency. "Demanding clients state their case: Comments on the client round table at La Rochelle" in The Journal of Specialised Translation, issue 1, January 2004, www.jostrans.org. Target readers were the 300 million men, women and children throughout the countries concerned by the Euro. Before translation began, source-text authors were asked to filter out the acronyms and central-banker-speak found in many official ECB documents, but even then, the initial round of translations was deemed user-unfriendly and revamped top to bottom. 
translators, noting "The longer you work with them and the better they understand your business philosophy, strategy and products, the more effective their texts will be ${ }^{2}$.

The same pamphlet reminds buyers that inquisitive translators are a plus; by identifying sections of text where clarification is needed, they allow companies to improve their original.

We would argue that it is precisely this willingness and ability to tease out implicit meaning that makes the difference. For in the final analysis, it is familiarity with a company's business model, in-house practices and existing documentation that gives translators the confidence they need to ask essential questions up front. And once they tackle a job, this familiarity is what helps forge the mental links needed to produce texts that work.

\section{Mission statements - the ideas and the words}

Corporate mission statements are an extreme case. At best, they summarize key principles driving a business and serve as rallying points for management and employees. At worst they come across as so much hot air, puffery that sharp-tongued journalists and other observers skewer with malicious delight ${ }^{3}$. A poor translation quickly crosses the line to become a parody, making it all the more important for the translator to serve up explicit and implicit content with flow and style.

Two different translations of the corporate mission statement of French food giant Danone are an example. The French original reads:

Partout dans le monde, faire grandir, mieux vivre et s'épanouir les hommes en leur apportant chaque jour une alimentation meilleure, des goûts plus variés, des plaisirs plus sains.

A first translation commissioned from a translation supplier claiming to specialize in business texts was clearly unsatisfactory: ${ }^{4}$

Throughout the world, to ensure that people can grow, live better and thrive to be full by providing them daily with better food, a greater variety of tastes and healthier pleasure.

And yet this was the text posted on the English version of the corporation's website. In-house teams at Danone were native French speakers

2. "Translation, getting it right" (Eng. ed.: ITI and ATA, 2000 \& 2003).

3. Examples abound; see management columnist Lucy Kellaway writing in The Financial Times.

4. A translation so dire in vocabulary, syntax and style that one can only wonder what sequence of events produced it (a first pass by translation software + dictionary look-up + human tweaking, all dictated over a crackly phone line?). 
and as such unable to judge the quality of the text delivered, a common problem that lies at the heart of many translation slip-ups and generates enormous frustration for clients.

When alerted to the problem, Danone management turned to a longstanding supplier and got better results:

Danone helps people around the world grow, live better and get more out of life through tastier, more varied and healthier food products - every day.

Significantly, this version was the result of lengthy discussions between translators and the company's management team, cross-revision by two native speakers of English, and proofreading once posted online. To be sure, the style alone is incomparably better. But the translators had also taken the time and effort to position themselves on the company's wave-length.

\section{Corporate values - get it right the first time}

In a similar vein, in 2002 Danone counted three "corporate values": bumanisme, ouverture et enthousiasme. These had been translated years earlier as "humanism", "openness" and "enthusiasm" - the first term clearly a mistranslation (a simple calque), the second and third awkward. Yet, executives explained, all three terms had been used for so long and appeared on so many official documents and applications that a change was not envisaged.

Happily, following retranslation of the mission statement, management was language-transfer-conscious enough to take proactive measures to ensure quality before adopting a fourth value, la proximité. This time, they contacted their translation team for an opinion well in advance - an English version was needed for international documents, but also for translation into a host of languages in local markets around the world. Would "proximity" work?

Once again, the translation team sought background information there was no question of flipping through a dictionary and pulling out a term. They learned that the French word had been selected following extensive use of focus groups, and asked what proximité covered for these groups.

A raft of positive concepts, said Danone, starting with accessibilité, authenticité and complicité. And what, precisely, did those concepts refer to? responded the translators.

Again management was happy to explain: Danone products are accessible in that they are available around the globe, at points of sale ranging from pushcarts on the streets of Mumbai to supermarkets in Berlin to 
mom \& pop shops in Cincinnati. They are also packaged to be accessible for local pocketbooks, with, for example, mini-packs of two vitaminenriched biscuits selling for a single rupee in India and larger, more expensive packages of fancier products on offer in countries where purchasing power is higher.

In English, proximity refers primarily to physical space, whereas Danone's authenticité and complicité describe "nearness" as an approach in tune with customers' lifestyles and perceived needs, e.g., healthy snacks for working mothers, low-calorie yogurts and biscuits for weight-watchers, etc.

But the notion was broader, too, the translators discovered, since it included Danone's commitment to finding new jobs for employees affected by restructuring; its willingness to offer internships to underprivileged teens; contributions to environmental causes in communities near production plants; and more.

Clearly "proximity" on its own was a pale copy.

In a first stage, the translators toyed with available / authentic / genuine / complicity / sharing before deciding that the concepts underlying proximité might be reasonably rendered as accessibility, credibility and empathy.

After further brainstorming, they then suggested two options for proximité: "In touch" and "Community". At the same time, they pointed out that the unfortunate mistranslation of humanisme might be mitigated by introducing a personalized definition: "At Danone (our emphasis), humanism means sharing, responsibility and respect for others." Using the same model, the company might also opt for "At Danone, proximity means accessibility, credibility and empathy" - which is the solution it ultimately adopted.

\section{Social responsibility revisited}

In France, Danone has long been known as a progressive employer, in keeping with arguments made by its founder and first CEO, the late Antoine Riboud, in a 1972 speech to the French employers' association in Marseilles.

Mr. Riboud described the company's business model as un double projet économique et social, a phrase translated for decades as the supremely opaque "dual economic and social project".

Once again, it was proactive translators who suggested that this word-for-word rendering did not do justice to the concept. Their proposal, "dual commitment to business success and social responsibility", 
helped bring home to non-French speakers the corporation's unionfriendly and people-oriented approach to profitable business.

\section{So what do these three examples tell us?}

That Groupe Danone executives take translation and communication seriously - a heartening message for translators prone to assuming (and sometimes stating outright) that clients "don't care what they get".

For some readers, the mission statement, corporate values and "dual project" adjustment may simply be examples of slapdash translations set right.

For the author, they are a reminder of the very exciting market that awaits translators prepared to go beyond the words to examine underlying concepts and issues and meaning. To bring these out into the open before deciding, with the client, what might be usefully stated more clearly for a given readership or instead returned to the shadows. L'implicite to the fore.

It is equally important to note that these examples are neither rewriting nor adaptation. They are translations, created by respecting both the explicit and implicit meaning of a text and the intent of its authors. The essential ingredient? Interaction with the client both before and during the assignment - the hallmark of the professional translator, and the key to a very satisfying career. 